\title{
Aeromonas Causes Severe Skin Lesions in Rainbow Trout (Oncorhynchus mykiss): Clinical Pathology, Haematology and Biochemistry
}

\author{
J. ŘEHULKA
}

University of South Bohemia, České Budějovice, Research Institute of Fish Culture and Hydrobiology, Vodňany, Department of Aquatic Toxicology and Fish Diseases, Laboratory Opava, Czech Republic

\section{Received March 23, 2002}

Accepted June 19, 2002

\section{Abstract}

Řehulka J.: Aeromonas Causes Severe Skin Lesions in Rainbow Trout (Oncorhynchus mykiss): Clinical Pathology, Haematology and Biochemistry. Acta Vet. Brno 2002, 71: 351-360.

Aeromonas infection caused mass death of rainbow trout, Oncorhynchus mykiss (Walbaum) weighing $394 \pm 69 \mathrm{~g}$, at a water temperature of $4^{\circ} \mathrm{C}$ in April. In a bioassay, the disease was induced by an Aeromonas strain whose biochemical characteristics most closely resembled Aeromonas sobria and Aeromonas caviae. The development of the skin lesions started as depigmented spots surrounded by a hyperaemic zone with the formation of ulcers, or the changes on the skin resembled furunculosis, taking the form of very large prominent bulges filled with clear exudate which, when broken, revealed haemorrhagically altered muscle. Some fish showed exophthalmus; inflammation around pectoral fins; hyperaemia of the wall of the swim-bladder and petechial haemorrhages on the liver were found inside the abdominal cavity. Severe anaemia was characterized by a reduced erythrocyte count and lower haematocrit and haemoglobin levels. Clinical chemistry analyses in the diseased fish indicated reduced levels of total protein, cholesterol, triacylglycerol and total calcium and an increase in the urea level. Among the five enzymes and isoenzymes analyzed, catalytic concentration reaching multiples of the normal level was found in alanine aminotransferase, lactate dehydrogenase, $\alpha$-hydroxybutyryl dehydrogenase and $\gamma$-glutamyl transferase. Electrophoretic analysis indicated a reduced level of albumin in the diseased fish. These results point out the importance of mesophilic motile Aeromonas as causal agents of severe skin affections in salmonids. The findings encourage efforts to extend the knowledge of clinical haematology for the identification of health disorders and specific responses typical of the individual diseases.

Aeromonas caviae, Aeromonas sobria, histopathology, red blood count, biochemical indices, blood plasma, electrophoresis

The care of the health of fish stocks in intensive salmonid culture necessitates the participation of qualified veterinary supervision. Among the suite of methods for examination of the physiological health of the fish, an increased awareness of the usefulness of clinical chemistry is materializing among first pathologists and veterinarians. Appropriate haematological and biochemical assays may identify changes in organ function, find anomalies in the metabolism, determine additional laboratory procedures and make prognoses. Synthesis and analysis of the figures obtained for the individual diseases may provide valuable information on the specific response or the range and nature of the pathological process. For salmonids this is confirmed by the analyses performed by Mulcahy (1969, 1971), Foda (1973), Shieh and MacLean (1976), Harbell et al. (1979), Hoffmann and Lommel (1984), Bruno (1986), Waagbø et al. (1988) and Møyner (1993).

Skin affections frequently occur in intensive salmonid culture. If they are identified in time, the development of the pathological process can be very effectively prevented. This applies, in particular, to cases in which the epizootic breaks out at a low water temperature when the voracity of the fish is low and the diseased fish are less willing to 
take medicated food so that the effectiveness of targeted therapeutic intervention is poor. In addition to flavobacterial infections, microbiologists have good reasons also to focus their interest on the motile mesophilic Aeromonas species as causative agents responsible for septicaemia, local inflammations and necroses on the skin, muscles and soft tissues. Apart from Aeromonas hydrophila, the aetiology of Aeromonas-related lesions may also involve certain species identified in recent years, including for example Aeromonas allosaccharophila, described in conger eel by Martinez-Murcia et al. (1992), or also described by us in the clinical material of isolated Aeromonas sobria and Aeromonas caviae. The authors of widely recognized identification systems (Arduino et al. 1988; Carnahan et al. 1991) assert that the identification of the individual species is difficult; others prefer identification of pathogenic factors together with biochemical traits rather than giving a strain a specific name (Agger et al. 1985; Burke et al. 1982).

The purpose of this report is to describe changes in the peripheral blood of rainbow trout in mass occurrence of Aeromonas natural infection. The basic characteristics of erythrocytes, certain metabolites of the blood plasma (including activities of the various enzymes) and changes in the plasma protein spectrum were examined. The findings extend, enhance and refine the knowledge learned from the given case, as described in a contribution to the V. International Ichthyohaematology Conference (̌̌ ehulka 1998).

Fish

Materials and Methods

The infection occurred early in April on a trout farm where the fish was kept in flow-through concrete tanks, were fed for the market (average weight was $370 \mathrm{~g}$ and standard length $300 \mathrm{~mm}$ ). The water temperature was $4^{\circ} \mathrm{C}$, dissolved oxygen content $11.8 \mathrm{O}_{2} \cdot 1^{-1}$, oxygen saturation $88 \%$, water hardness $3.4^{\circ} \mathrm{N}$ and $\mathrm{COD}_{\mathrm{Mn}} 0.8 \mathrm{mg} \cdot \mathrm{l}^{-1}$. The disease took a chronic course, mortality reached $50 \%$. Selected for the investigation were fish with lesions of the same nature as shown in Figs 1 and 2 (Plate XII), manifested in 90\% of the affected fish.

Sampling procedure for histopathology

Tissue samples from 8 moribund fish, including muscle, heart, kidney, liver, spleen and intestine, were fixed in a $10 \%$ neutral buffered formalin solution. Histologic sections were stained by haematoxylin-eosin and Gram.

Bacteriology

Bacteriological procedures consisted of the preparation and Gram staining of tissue smears, inoculation of growth media and evaluation of microbial cultures. Tissues from the edges of the skin lesions, exudate from the lesions, and tissues of the internal organs were subjected to these bacteriologic procedures. Blood agar (Columbia Agar Base MERCK), cytophaga agar (Pacha and Ordal 1967), tryptone soya agar (TSA, Oxoid), KDM2 (Evelyn 1977) and sweet wort agar (Fassatiová 1979) served as the culture.

Experimental infection of the fish

Infection trials were performed to identify the causative agent of the disease. Infection assays were conducted using 5 fish held in 200-litre flow-through tanks. Rainbow trout weighing about $200 \mathrm{~g}$ (some transferred from a tank free of the diseases, some from a laboratory where they had been kept for experimental purposes) were used as the experimental fish. Fish in one of the experimental groups were infected intramuscularly $(0.4 \mathrm{ml})$ and intraperitoneally $(0.8 \mathrm{ml})$ using exudate from the skin lesion (see Plate xx, Fig. 3). Other experimental groups were infected by the same route, using individual bacterial isolates propagated for $24 \mathrm{~h}$ in $10 \mathrm{ml}$ of a meat-peptone bouillon six days after isolation from the affected fish. The fish in the control group were inoculated with a liquid medium free of the bacteria. The fish were examined daily for 14 days, and dead and moribund fish were examined bacteriologically, as described above. The trials were performed at a water temperature of $7-9{ }^{\circ} \mathrm{C}$, water hardness $3.4^{\circ} \mathrm{N}$ and dissolved oxygen level of $11 \mathrm{mg} \cdot \mathrm{l}^{-1}$.

Preparation of the blood samples

Blood was sampled from the 8 fish with clinical signs of the disease and from another 8 clinical healthy fish with a negative bacterial finding coming from the site where the affected fish occurred. The sampling was performed 20 $\mathrm{h}$ after the last feeding.The fish were anesthetized with Menocaine /3-ethoxycarbonylfenyl/ ammonium natrium hydrogensulfuricum in concentration $0.1 \mathrm{~g} \cdot \mathrm{l}^{-1}$ and then the blood sample was taken by puncturing the caudal veins between 08.00 and $11.00 \mathrm{~h}$. EDTA and sodium heparin (5000 IU in $1 \mathrm{ml}$ injection) were used as anticoagulants, the former being used for the haematological examination and the latter for the biochemical analyses of the blood 
plasma. During blood sampling, water temperature was $4{ }^{\circ} \mathrm{C}$, oxygen saturation of water $88 \%$, water hardness 3.4 ${ }^{\circ} \mathrm{N}$ and $\mathrm{COD}_{\mathrm{Mn}} 0.8 \mathrm{mg} \mathrm{O}{ }_{2} \cdot \mathrm{1}^{-1}$.

Haematology and clinical chemistry

The red blood cell counts (RBCc T $\left.\cdot 1^{-1}\right)$ were determined with a Bürker heamocytometer and in Hayem solution. Erythrocytes were counted in $2 \times 20$ rectangles per sample. Haematocrit (Hct) was analyzed in microhaematocritheparinized capillaries, using a microhaematocrit centrifuge (15 $300 \mathrm{~g}$ for $3 \mathrm{~min}$ ). Haemoglobin $\left(\mathrm{Hb} \mathrm{g} \cdot \mathrm{l}^{-1}\right) \mathrm{was}$ determined by the cyanhaemoglobin method, photometrically at a wavelength of $540 \mathrm{~nm}$. The derived blood indices of mean corpuscular volume $(\mathrm{MCV} \mathrm{fl})$, mean corpuscular haemoglobin $(\mathrm{MCH} p g)$, and mean corpuscular haemoglobin concentration (MCHC) were calculated from the haematological data.

The biochemical indices of the blood plasma were determined within $24 \mathrm{~h}$ of storage at $4{ }^{\circ} \mathrm{C}$; a Hitachi 704C instrument was used for the determinations, involving the C.f.a.s. calibrator for automatic systems (Roche production batch). These included total protein (TP $\mathrm{g} \cdot \mathrm{l}^{-1}$ ), blood urea nitrogen (BUN mmol $\cdot \mathrm{l}^{-1}$ ), uric acid (UA $\left.\mu \mathrm{mol} \cdot \mathrm{l}^{-1}\right)$, creatinine $\left(\mathrm{CREA} \mu \mathrm{mol} \cdot \mathrm{l}^{-1}\right)$, glucose $\left(\mathrm{GL} \mathrm{mmol} \cdot \mathrm{l}^{-1}\right)$, cholesterol $\left(\mathrm{CHOL} \mathrm{mmol} \cdot \mathrm{l}^{-1}\right)$, triacylglycerol (TGL mmol $\cdot \mathrm{l}^{-1}$ ), total bilirubin (T-BIL $\left.\mu \mathrm{mol} \cdot \mathrm{l}^{-1}\right)$, catalytic concentration of alanine aminotransferase (ALT $\left.\mu \mathrm{kat} \cdot \mathrm{1}^{-1}\right)$, aspartate aminotransferase $\left(\mathrm{AST} \mu \mathrm{kat} \cdot \mathrm{l}^{-1}\right)$, lactate dehydrogenase (LD $\left.\mu \mathrm{kat} \cdot 1^{-1}\right)$, $\gamma$-glutamyl transferase (GMT $\mu$ kat $\left.\cdot 1^{-1}\right)$, and $\alpha$-hydroxybutyryl dehydrogenase (HBD $\mu$ kat $\cdot 1^{-1}$ ). The content of total calcium $(\mathrm{Ca}$ $\left.\mathrm{mmol} \cdot \mathrm{l}^{-1}\right)$ was determined by flame emission photometry and inorganic phosphate $\left(\mathrm{P}\right.$ mmol. $1^{-1}$ was determined spectrophotometrically.

The electrophoretic separation of protein was performed on agarose gel at $\mathrm{pH} 8.6$, at a separation tension of 15 to $20 \mathrm{~V} \mathrm{~cm}-1$, temperature of $10^{\circ} \mathrm{C}$ and separation time of $45 \mathrm{~min}$, using the LKB 2117 Bromma Multiphor II apparatus. The laser densitometer was used for the qualitative and quantitative assessment of the protein fractions, with graphic recording.

Statistical analysis

In compliance with the objective of the study, mathematic-statistical methods were used to describe the selected sets from the one-dimensional and multidimensional aspects. Data from the healthy and diseased fish were compared using the $F$ - test and Student's $t$ - test. All the calculations were made using the statistical package UNISTAT ${ }^{\circledR}$ for MS Windows ${ }^{\text {TM }}$. All the used procedures are described user's guide (1995).

For the graphic representation of the results we used notch box graphs with filaments, where $\mathrm{a}=$ width of the box, indicating the size of the set, $b=$ mid diagonal of the box, representing the position of the median in relation to the $y$ axis, $c=$ mark inside the box showing the position of the arithmetic mean, $d=$ lower and upper edge of the box indicating successively the position of the lower and upper quartiles, $\mathrm{e}=$ width of the notch, corresponding to the confidence interval around the median, $\mathrm{f}=$ the lower filament having a length corresponding to the value of the lower quartile reduced by 1.5 times the span of the quartiles. If this value is lower than the minimum value in the set the length of the filament corresponds to this minimum value. If values lower than those corresponding to the coordinate of the end point of the lower filament do occur in the set, then these values are signaled as remote, $g=$ the upper filament having a length corresponding to the value of the upper quartile enlarged 1.5 times the span of the quartiles. If this value is higher than the maximum value in the set the length of the filament corresponds to this maximum value. If values higher than those corresponding to the coordinate of the end point of the upper filament do occur in the set, then these values are signaled as remote.

\section{Results}

Clinical signs and gross pathology and histopathology

The gross lesions of the skin varied. The depigmented erosions of various sizes, occurring mainly on the sides near the gill covers (Plate XII, Figs 1 and 2) were considered to be the stage of the changes. Enormous prominent bulges developed on the skin of $10 \%$ of the fish (Plate XIII, Fig. 3); the lesions were filled with clear to slightly turbid exudate, in some cases with a slight tint of blood. On cut section they exposed haemorrhagically altered muscle (Fig. 4). As distinct from furunculosis, the muscle does not disintegrate under the skin bulge and does not produce crater-like furuncles because the pathological process did not reach deeper layers. The majority of the fish had pale gills, indicating different degrees of anaemia. Some had exophthalmus and inflammations around the bases of the pectoral fins. The findings inside the abdominal cavity included hyperaemia on the wall of the swim-bladder, small haaemorrhages in the liver, splenomegalia and dampness throughout the internal organs.

The histological findings of the skin lesions included a necrotizing granulocytic inflammation with no distinct borders and with an abundant exudative component, and disintegration of the muscle fibers with a marked interstitial inflammatory oedema. The 
characteristic changes are documented in Figs 5 and 6 (Plate XIV). The kidneys showed signs of albumin dystrophy and formation of hyaline droplets in the epithelium of proximal tubules. The wall of the macroscopically altered swim-bladder was thickened, congested and infiltrated eedematous matter.

Bacteriology

Three Aeromonas species/strains (Aeromonas hydrophila, Aeromonas media and strain A) and also Staphylococcus hicus, Staphylococcus epidermidis and Enterobacter cloacae were isolated from the edges of the open skin lesions, from the exudate taken from closed lesions and from the internal organs. Two species of fungi, Cladosporium herbarum and Cladosporium sphaerospermum, were also isolated from the clear exudate and from the closed skin lesions. Strain A, which played the most important role in the etiology of the disease, gave the following biochemical results:

Positive response: lipase; arginine dihydrolase; oxidase

Negative response: $\mathrm{H}_{2} \mathrm{~S}$ production; mannitol, acid; lysine decarboxylase; indole production; ornithine decarboxylase; citrate, Simmons; urea hydrolysis; ONPG; VogesProskauer; inositol, acid; lipase; phenylalanine deaminase; maltose, acid; adonitol, acid; cellobiose, acid; rhammose, acid; sucrose, acid; sorbitol, acid; esculin hydrolysis; trehalose, acid; dulcitol, acid; motility; gelatin hydrolysis; lactose, acid; arabinose, acid; pigment.

According to the bioassays and the scheme by Aldová (1994), the strain most closely resembled the species Aeromonas sobria (mannitol 98\%, sucrose 98\%, arabinose 7\%+) and Aeromonas caviae (mannitol 92\%, sucrose 97\% +, arabinose 69\% +). We excluded our initial tentative identification as Aeromonas schubertii (К̌ehulka 1998), which should have had a positive lysine, and also Aeromonas trota, which might also have negative mannitol $(83 \%+)$ and which, however, was only found in southeast Asia.

\section{Experimental infection}

In the test fish, intraperitoneal infection with an exudate from a closed skin lesion produced a swelling at the puncture site surrounded by depigmentation ( $62 \mathrm{~h})$; the infected fish refused food and kept away from the shoal $(86 \mathrm{~h})$; this was followed by agony and death $(168 \mathrm{~h})$. The post-mortem examination revealed congestion of the bases of pectoral fins, ascites, petechial haemorrhages in the liver and hyperaemia of the swim-bladder. In trials with individual bacterial isolates, the only strain with which we succeeded to reproduce the disease with manifestation of skin lesions was strain A: the disease was so induced with intraepidermal and intramuscular infection and with death after 48, 144 and $312 \mathrm{~h}$. During the post-mortem examination of the fish infected with this strain, which was re-isolated, contact of the culture with the surface tissue of pyloric appendages produced exudative fibrinous purulent inflammation (Plate XV, Figs 7 and 8), which was also found in fish infected by the exudate.

Haematology and clinical chemistry

To document the haematological and biochemical indices, we submit a series of Figs 9 to 20. The figures indicate that the affected fish had markedly reduced parameters characterizing the erythrocytes: their RBCc values ranged from 0.17 to $0.9(P=0.004)$, Hct from 0.09 to $0.283(P=0.001)$ and $\mathrm{Hb}$ from 14 to $45.7(P=0.000)$. For the healthy fish, on the other hand, the RBCc range was from 0.78 to 1.06 , Hct 0.294 to 0.411 and $\mathrm{Hb} 57.1$ to 78.7. As to the biochemical indices, there was a marked decline in TP (6.5-22 vs 33.3-38.1, $P=0.000)$, CHOL (0.34-1.89 vs 5.1-7.4, $P=0.000)$ ), TGL $(0.18-0.62$ vs $1.53-2.99, P=$ $0.000)$ and $\mathrm{Ca}(1.38-2.78$ vs $2.79-3.49, P=0.001))$. An increase was recorded in BUN (0.92.8 vs $0.2-1, P=0.003)$. As to the five enzymes tested, catalytic concentration reaching 

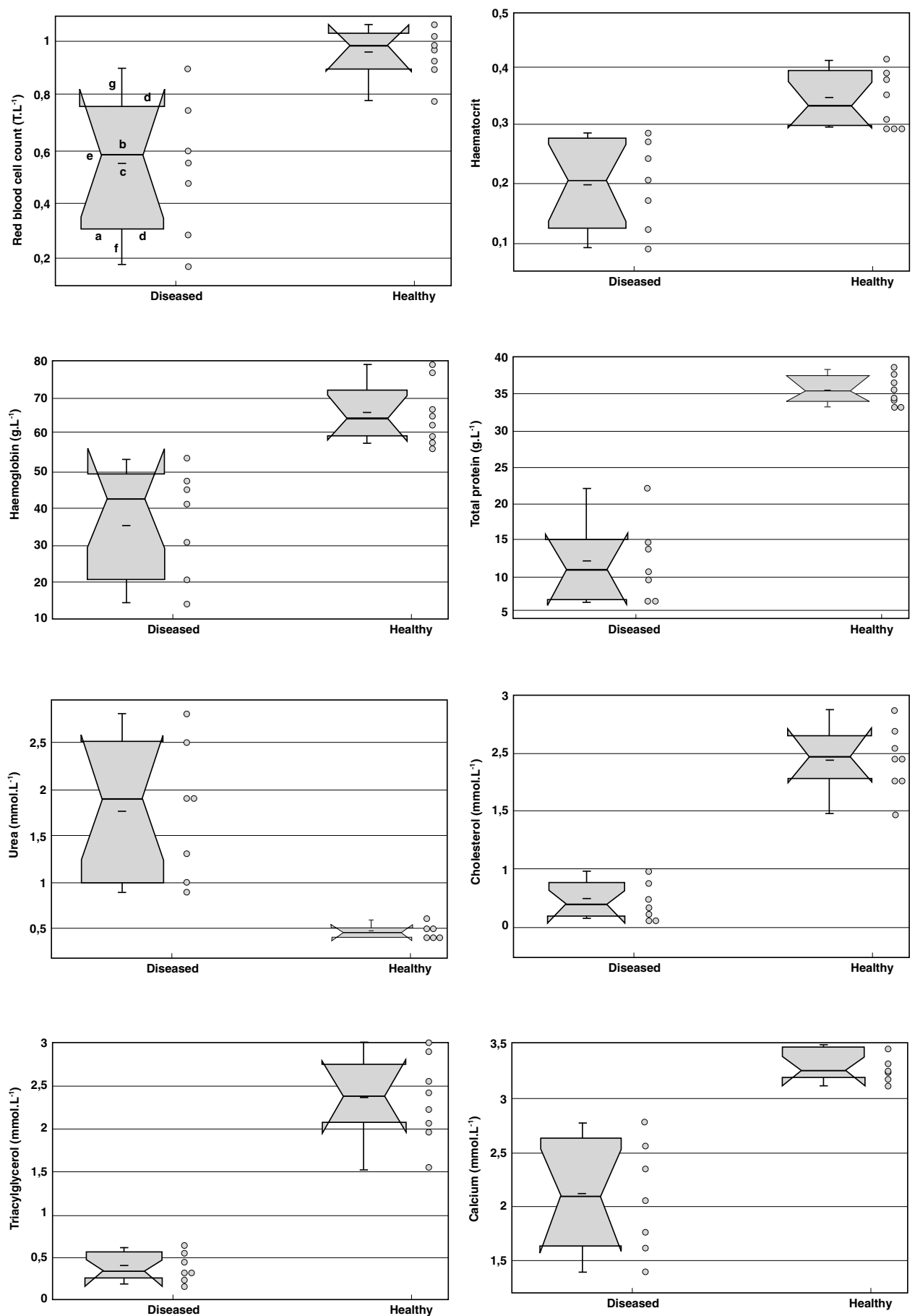

Fig 9-16. Haematological and biochemical indices in diseased and healthy fish 
multiples of the normal level was found in ALT (0.67-13 vs 0.25-1.24, $P=0.048)$, LD (12.89-86.32 vs 3.13-36.33, $P=0.023)$, HBD (4.11-65.59 vs $1.5-8.29, P=0.001)$ and GMT $(0.12-0.96$ vs $0.01-0.25, P=0.021)$. An unchanged catalytic concentration - yet with a high variability - was recorded in AST $(P=0.001)$.

Exudate from skin shown in Fig. 3, Plate XIII, was also subjected to biochemical analysis. Comparison of the values obtained from the analysis of the exudate with those from the blood plasma of the moribund and healthy fish, as shown in Table 1, suggests that the high level of BUN, the absence of CREA and a low GL.

Table 1

Biochemical examination of the exudate from the bulge (see Fig. 3) and a comparison thereof with the analyzed samples of the blood plasma

\begin{tabular}{|l|c|c|}
\hline Indices & Exudate & Plasma \\
\hline Total protein $\mathrm{g} \cdot \mathrm{l}^{-1}$ & 13.7 & 10.8 \\
Urea mmol $\cdot \mathrm{l}^{-1}$ & 22.2 & 0.9 \\
Creatinine $\mu \mathrm{mol} \cdot \mathrm{l}^{-1}$ & 0 & 3 \\
Glucose $\mathrm{mmol} \cdot \mathrm{1}^{-1}$ & 0.45 & 4.63 \\
Cholesterol $\mathrm{mmol} \cdot \mathrm{l}^{-1}$ & 1.03 & 0.72 \\
Triacylglycerol mmol $\mathrm{l}^{-1}$ & 0.78 & 0.47 \\
Inorganic phosphate $\mathrm{mmol} \cdot \mathrm{l}^{-1}$ & 2.36 & 3.51 \\
Total calcium mmol $\cdot \mathrm{l}^{-1}$ & 1.87 & 2.78 \\
Alanine aminotransferase $\mu \mathrm{kat} \cdot \mathrm{l}^{-1}$ & 1.83 & 1.67 \\
Aspartate aminotransferase $\mu \mathrm{kat} \cdot \mathrm{l}^{-1}$ & 12.11 & 13.74 \\
Lactate dehydrogenase $\mu \mathrm{kat} \cdot \mathrm{l}^{-1}$ & 25.97 & 24.9 \\
$\alpha$-hydroxybutyryl dehydrogenase $\mu \mathrm{kat} \cdot \mathrm{l}^{-1}$ & 10.78 & 9.45 \\
$\gamma$-glutamyl transferase $\mu \mathrm{kat} \cdot \mathrm{I}^{-1}$ & 0.18 & 0.96 \\
\hline
\end{tabular}

Electrophoretic examination was able to detect, on the whole, 11 plasma protein fractions (PPF 1 to PPF 11), of which PPF 1,2,3 were included in the albumin zone, PPF 4,5,6,7 in the $\alpha$-globulin zone, PPF 8,9,10 in the $\beta$-globulin zone and PPF 11 in the $\gamma$-globulin zone. The main findings in the diseased fish (Plate XVI, Fig. 21a), compared with the healthy fish (Fig. $21 \mathrm{~b}$ ), was a decrease in the proportion of the albumin fractions, of which PPF 1 fell to a level eight times lower (0.02 vs 0.16) and PPF 2 and PPF 3 to a level twice lower (0.22 vs 0.37). A marked reduction was also found in PPF 9 (0.046 vs 0.085). A significant increase occurred in PPF 7 (0.107 vs 0.061) and PPF 11 (0.098 vs 0.073). It is interesting to note that PPF 8 was present only in the diseased fish.

The results of the electrophoretic analysis of the protein of the exudate (Fig. 21c) most closely resemble the nature of electrophoreograms of the plasma of the diseased fish. The composition of the exudate with a high BUN and low GL correspond to the nature of bacterial inflammation.

It is considered interesting that the moribund fish were in a better condition, as far as nutrition is concerned, than the healthy fish: their condition coefficient was $1.66 \pm 0.047$ $($ mean $\pm \mathrm{SEM})$ whereas that of the healthy fish was $1.42 \pm 0.039(P=0.001)$.

\section{Discussion}

A decline in the values of RBCc, Hct and $\mathrm{Hb}$, associated with symptoms of severe anaemia, was recorded by Waagb $\varnothing$ et al. (1988) in Atlantic salmon, Salmo salar with the 'Hitra disease'; Harbell et al. (1979) recorded the same in coho salmon, Oncorhynchus kisutch experimentally infected with a highly virulent Vibrio anguillarum. Also Cardwell and Smith (1971) did find a progressive effect on Hct and Hb in juvenile chinook salmon 

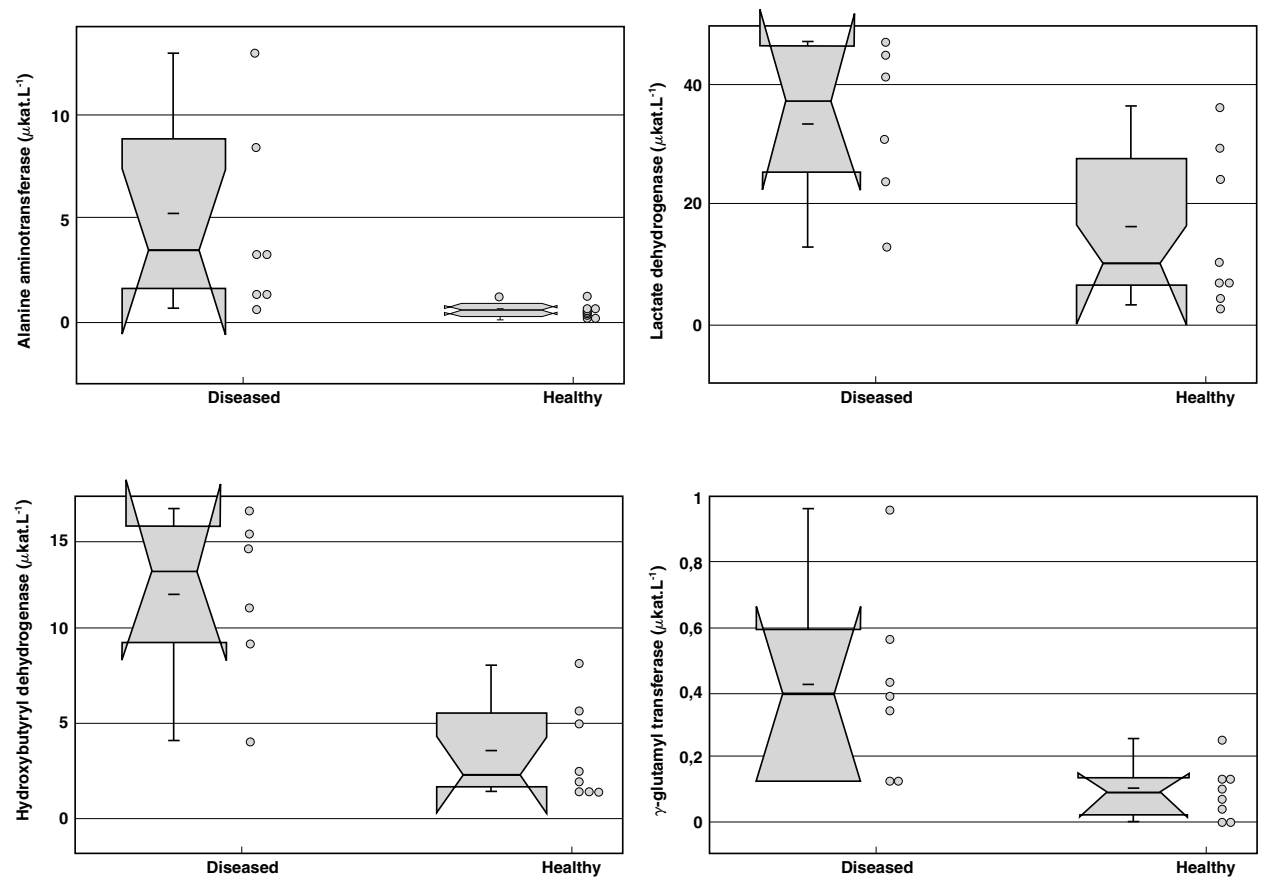

Fig 17-20. Haematological and biochemical indices in diseased and healthy fish

with vibriosis. For a severe Aeromonas infection in Atlantic salmon, Fod a (1973) described a decrease in $\mathrm{Hb}$. Amend and Smith (1974) demonstrated a reduction in RBCc, Hct and $\mathrm{Hb}$ in IHN virus-infected rainbow trout. A decline in $\mathrm{RBCc}$, Hct and $\mathrm{Hb}$, combined with signs of anaemia, was also described by Hoffmann and Lommel (1984) in cases of proliferative kidney disease (PKD). The non-significant differences in $\mathrm{MCV}, \mathrm{MCH}$ and $\mathrm{MCHC}$ between the diseased and healthy fish testify to the fact that the anemia was due, in particular, to blood losses from the skin lesions; in agreement with the findings of W a a g $\varnothing \varnothing$ et al. (1988), these blood indices indicated active erythropoiesis to compensate for the loss.

We recorded - and so did other authors - a decline in TP in salmonids affected by infectious diseases: Mulcahy (1971) did so in the serum of the brown trout and Atlantic salmon with ulcerative dermal necrosis (U.D.N.) and single fungal infection (Saprolegnia ferax) and in salmon fingerlings with fin rot and furunculosis (Mulcahy 1969). Hypoproteinaemia was reported by Harbell et al. (1979) to occur in this salmon with vibriosis, and Hunn (1964) found it to occur in brook trout with corynebacterial kidney disease. A decrease in TP, TGL and CHOL in the serum of Atlantic salmon suffering from cold-water vibriosis is described by Waagb $\varnothing$ et al. (1988).

Unlike Harbell et al. (1979) we did not find an increased GL but what we did find was a reduced $\mathrm{Ca}$ level (though the above authors claim that the Ca level is about the same in both moribund and healthy fish). Wa a gb $\varnothing$ et al. (1988) described a four times lower level of CREA but in our essays this parameter - though also slightly decreased - were highly balanced in comparison with the healthy fish. Our evaluation of the catalytic activity of amino transferases matched the results published by Waagb $\varnothing$ et al. (1988) who had also recorded an unchanged catalytic concentration of AST in the Atlantic salmon with vibriosis; however, they had recorded an increased ALT activity. Harbell et al. (1979), in turn, had found an increased catalytic AST activity in cases of vibriosis in coho salmon. The increase 
in LD found by us is the same as what Harbell et al. (1979) and also Racicot et al. (1975) had found in rainbow trout with Aeromonas infection.

As to the results of the electrophoretic analysis, the highest importance is attached to the decline of the albumin fractions which were most significantly involved in the hypoproteinaemia. The low level of albumin may be the result of losses from the skin lesions, an increased catabolism in acute inflammation or reduced synthesis due to hepatopathy, or may be related to a renal damage. What can also be considered important is the reduction of PPF 9 (the $\beta$-globulin zone) and the manifestation of PPF 8 , not detected in healthy fish. A decline in the $\beta$, fraction when disc acrylamide gel system was used was described by Harbell et al. (1979) in coho salmon with vibriosis.

The increase in the BUN level is probably associated with an escalated protein catabolism which grows with fasting, infection and loss of blood. A greater increase in BUN over CREA may be indicative of pre-renal uraemia which is caused by hypovolaemia - a condition at which glomerular filtering declines and absorption of BUN grows (and so does BUN presence in the plasma). The enormous and highly significant $(P=0.001)$ correlation of total bilirubin with urea $(\mathrm{r}=0.949$, T-BIL $=-1.4336+1.4419$ BUN or BUN $=1.0700+0.6247$ T-BIL) can probably be ascribed to the accelerated catabolism of albumin and release of non-conjugated bilirubin from its link to albumin. As known in homoiotherms (Racek 1999), the link to albumin is reduced by acidemia, with accumulation of acid endogenous metabolites leading to metabolic acidosis which may have the nature of lactic acidosis combined with insufficient oxygenation of the blood and with tissue hypoxia. This condition corresponds to anaemic hypoxia caused by an erythrocyte or haemoglobin defect or anaemia. The considerable decrease in the CHOL levels is in agreement with the findings published by $\mathrm{Waagb} \emptyset$ et al. (1988) and might be related to a damage to liver, uraemia and sepsis. The marked decline in Ca which, in the plasma, is linked to albumin, can be ascribaed to hypoproteinaemia.

The increase in the catalytic activity of ALT is probably related with a damage to the membranes of hepatocytes. The higher levels of LD and HBD correlate with the described pathological changes in the skin lesions.

The report draws attention to the importance of mesophilic motile Aeromonas strains as the causal agents responsible for severe skin lesions in salmonids. Compared with furunculosis, the disease has different clinical manifestations, develops in a different period of the year and has strange pathological characteristics. All this encourages researchers to continue studying the conditions and causal relations underlying the disease. On the basis of differential diagnosis in bioassays, scientists are trying to identify the causative agent of the disease among the isolated strains. This was confirmed by our other findings in the brook trout affected on mass in intensive culture, as well as in eel and chub in dam reservoirs. Toranzo et al. (1989) found Aeromonas sobria to be associated with outbreaks of fatal disease in gizzard shad (Dorosoma cepedianum) and showed it to be pathogenic to rainbow trout in trhe laboratory.

As to the underlying factors, what can be considered to be related to the rise of the disease described by us is the occasional water pollution with municipal sewage; in the case of eel and chub the disease may be ascribed to the development of water eutrophication. As asserted by Shotts et al. (1972) eutrophication caused by pollution with farm waste supports increased occurrence of mesophilic aeromonads and their pathogenicity to the inhabitants of the aquatic environment, including fish, frogs and slugs. Increased occurrence of motile aeromonads in waters with high sewage levels is reported by Geldreich (1973). Unfortunately, the disease was recognized too late, so that we were unable to record evidence relating to this type of pollution. As mentioned, at the time of the investigation the physical and chemical properties of the water complied with the requirements for salmonid culture. 
The results presented in the paper provide a basis for further comparative studies aimed at obtaining detailed information on the patho-physiological processes in the blood in cases of Aeromonas infection. This will be important for using such knowledge in the screening programs under methods of examination of the state of health of salmonids in intensive culture.

\section{Aeromonádová onemocnění pstruha duhového (Oncorhynchus mykiss Walbaum): patologické, hematologické a biochemické změny}

Aeromonádová infekce byla přičinou hromadného úhynu pstruhů duhových, Oncorhynchus mykiss (Walbaum) o hmotnosti $394 \pm 69 \mathrm{~g}$ při teplotě vody $4{ }^{\circ} \mathrm{C}$ v měsíci dubnu. Biologickým pokusem bylo onemocnění vyvoláno aeromonádovým kmenem, jehož biochemické vlastnosti se nejvíce podobaly Aeromonas sobria a Aeromonas caviae. Další izoláty tvořily Aeromonas media, Aeromonas hydrophila, Staphylococcus hicus, Staphylococcus epidermidis, Enterobacter cloaceae a nesacharolytický Acinetobacter. Vývoj kožních lézí začínal depigmentovanými skvrnami s hyperémickou zónou v okolí a tvorbou vředů nebo změny na kůži připomínaly furunkulózu a byly tvořeny obrovsky prominujícími boulemi naplněnými čirým výpotkem, které po prasknutí obnažovaly hemoragicky změněnou svalovinu. U některých ryb se nacházel exoftalmus a zánět kolem báze prsních ploutví, $v$ dutině břišní byla nalezena hyperémie stěny plynového měchýře a petechiální krváceniny na játrech. Těžká anémie byla charakterizována sníženým počtem erytrocytů, poklesem hematokritu a hemoglobinu. $\mathrm{Z}$ biochemických ukazatelů krevní plazmy došlo ke snížení celkové bílkoviny, cholesterolu, triacylglycerolu a celkového vápníku a ke zvýšení hladiny močoviny. $Z$ pěti testovaných enzymů a izoenzymů byla několikanásobně zvýšena katalytická koncentrace alaninaminotransferázy, laktátdehydrogenázy, $\alpha$-hydroxybutyryl dehydrogenázy a $\gamma$-glutamyl transferázy. Elektroforeticky byl u nemocných ryb zjištěn především snížený podíl albuminu. Dosažené výsledky aktualizují význam mesofilních pohyblivých aeromonád, jako původců závažných kožních afekcí intenzivně odchovávaného pstruha duhového.

\section{Acknowledgements}

The study was conducted with the support of Grant No.525/00/0241 awarded by the Grant Agency of the Czech Republic. Author thanks DrE Aldová of the National Institute of Public Health in Prague for help with identification of Aeromonas strains and Assoc. Prof. J. Horáček M.D. PhD. of the Medico-Social Faculty of the Ostrava University for consultations relating to the results of histological examinations. Thanks also go to Prof. B. Minařík PhD., of the Mendel University of Agriculture and Forestry in Brno, Department of Statistics, for the graphical and mathematical processing of the results.

\section{References}

AGGER, WA, McCORMICK, JD, GURWITH, MJ 1985: Clinical and microbiological features of Aeromonas hydrophila-associated diarrhea. J Clin Microbiol 21: 909-913

ALDOVÁ, E., SCHINDLER, J., URBÁŠKOVÁ, P., NĚMEC, A. 1994: Biochemical identification of aeromonads. Epidemiologie, Mikrobiologie, Imunologie 43: 55-60 [In Czech]

AMEND, DF, SMITH, L 1974: Pathophysiology of infectious hematopoietic necrosis virus disease in rainbow trout (Salmo gairdneri): Early changes in blood and aspects of the immune response after injection of IHN virus. J Fisheries, Research Board of Canada 31: 1371-1378

ARDUINO, MJ, HICKMANN-BRENNER, FW, FARMER, JJ 1988: Phenotypic analysis of 132 Aeromonas strains representing 12 DNA hybridization groups. CDC Atlanta, Ga, International Symposium on Aeromonas and Plesiomonas, Sept. 1988, Miami Beach, Florida,USA.

BRUNO, DW 1986: Changes in serum parameters of rainbow trout, Salmo gairdneri Richardson, and Atlantic salmon, Salmo salar L., infected with Renibacterium salmoninarum. J Fish Dis 9: 205-211

BURKE, V, ROBINSON, J, ATKINSON, HM, GRACEY, M 1982: Biochemical characteristics of enterotoxigenic Aeromonas spp. J Clin Microbiol 15: 48-52

CARDWELL, RD, SMITH, LS 1971: Hematological manifestations of vibriosis upon juvenile chinook salmon. Progressive Fish-Culturist 33: 232-235 
CARNAHAN, AM, BEHRAM, S, JOSEPH, SW 1991: Aerokey II, A flexible key for identifying clinical Aeromonas species. J Clin Microbiol 29: 2843-2849

EVELYN, TPT 1977: An improved growth medium for the kidney disease bacterium and some notes on using the medium. Bulletin de 1'Office International des Epizooties 87: 511-513

FASSATIOVÁ, O. 1979: Moulds and filamentous fungi in technology. SNTL, Praha, 211 p. [In Czech]

FODA, A 1973: Changes in hematocrit and hemoglobin in Atlantic salmon (Salmo salar) as a result of furunculosis disease. J Fisheries Res Board of Canada 30: 467-468

GELDREICH, EE 1973: Microbiology of Water. J Water Pollution 45: 1244-1259

HARBELL, SC, HODGINS, HO, SCHIEWE, MH 1979: Studies on the pathogenesis of vibriosis in coho salmon, Oncorhynchus kisutch (Walbaum). J Fish Dis 2: 391- 404

HOFFMANN, R, LOMMEL, R 1984: Haematological studies in proliferative kidney disease of rainbow trout, Salmo gairdneri Richardson. J Fish Dis 7: 323-326

HUNN, J 1964: Some pathophysiological effects of kidney disease in brook trout. Proc Soc Exper Biol Med 117:383-385

MARTINEZ-MURCIA, AJ, ESTEVE, C, GARAY, E, COLLINS, MD 1992: Aeromonas allosaccharophila sp. nov., a new mesophilic member of the genus Aeromonas. FEMS Microbiology Letters 91: $199-206$

MULCAHY, MF 1969: Serum protein changes in UDN-infected Atlantic salmon: A possible method of diagnosis. J Fish Biol 1: 333-338

MULCAHY, MF 1971: Serum protein changes associated with ulcerative dermal necrosis (UDN) in the trout, Salmo trutta L. J Fish Biol 3: 199-201

MØYNER, K 1993: Changes in serum protein composition occur in Atlantic salmon, Salmo salar L., during Aeromonas salmonicida infection. J Fish Dis 16: 601-604

PACHA, RE, ORDAL, EJ 1967: Histopathology of experimental columnaris disease in young salmon. J Comp Pathol 77: 419-420

RACEK, J 1999: Klinická biochemie. Galén, $317 \mathrm{p}$.

RACICOT, JG, GAUDET, M, LERAY, C 1975: Blood and liver enzymes in rainbow trout (Salmo gairdneri) with emphasis on their diagnostic use: Study of $\mathrm{CCl}_{4}$ toxicity and case of Aeromonas infection. J Fish Biol 7: 825 835

ŘEHULKA, J 1998: Blood indices of the rainbow trout, Oncorhynchus mykiss (Walbaum) in Aeromonas-induced ulcerous dermatitis. In: V. International Ichthyohaematology Conference, November 30-December 3, 1998 (Eds BARANYIOVÁ, E, VYKUSOVÁ, B, SVOBODOVÁ, Z). Acta Vet Brno 67: 317-322

SHIEH, HS, MacLEAN, JR 1976: Blood changes in brook trout induced by infection with Aeromonas salmonicida. J Wildlife Dis 12: 77-83

SHOTTS, EB, GAINES, JL, MARTIN, L, PRESTWOOD, AK 1972: Aeromonas induced deaths among fish and reptiles in an eutrophic inland lake. J Amer Vet Med Assoc 161: 603-607

TORANZO, AE, BAYA, AM, RONALDE, JL, HERICK, FM 1989: Association of Aeromonas sobria with mortalities in adult gizzard shark, Dorosoma cepediamum Lesueur. J of Fish Dis 12: 439-448

WAAGBØ, R, SANDNES, K, ESPELID, S, LIE, O 1988: Haematological and biochemical analyses of Atlantic salmon, Salmo salar L., suffering from coldwater vibriosis ('Hitra disease'). J Fish Dis 11: 417-423 
Plate XII

Řehulka J.: Aeromonas... pp. 351-360

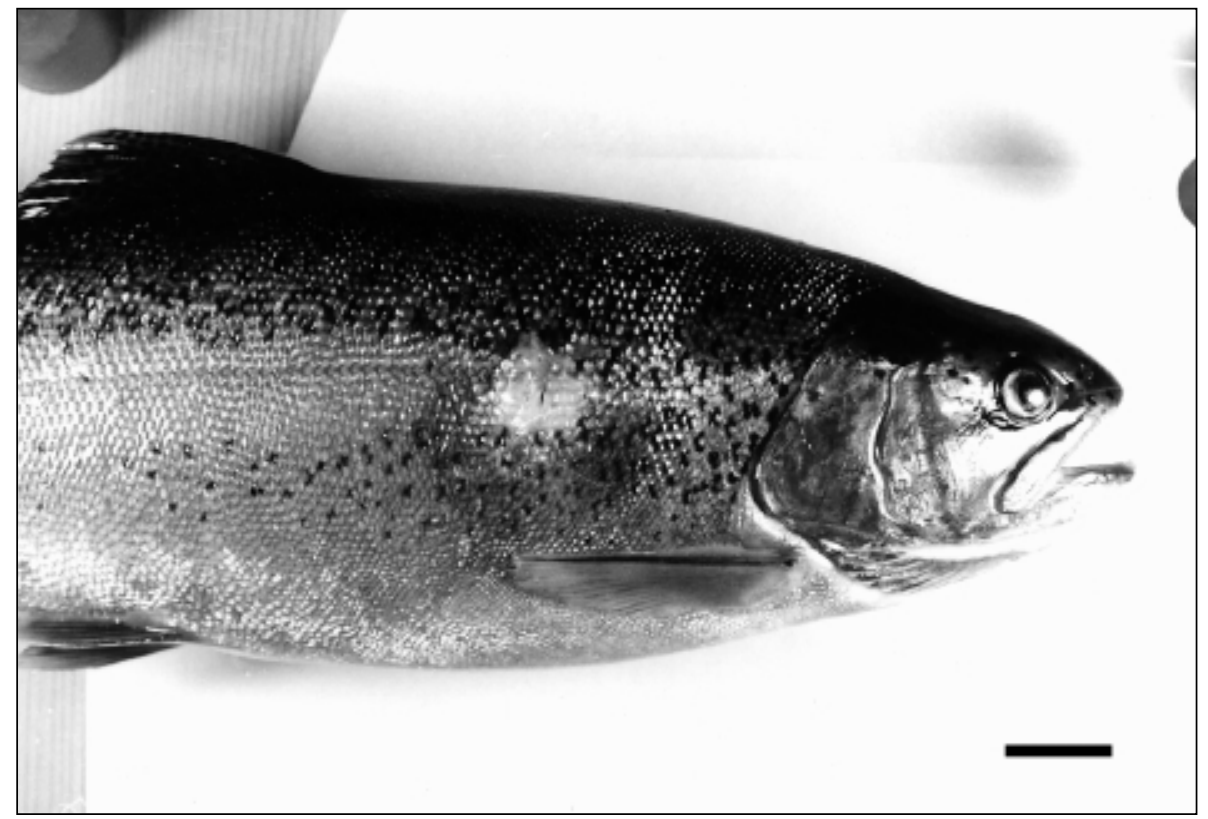

Fig. 1. Early lesion on the skin surface surrounded by a hyperaemic zone. Bar $=20 \mathrm{~mm}$.

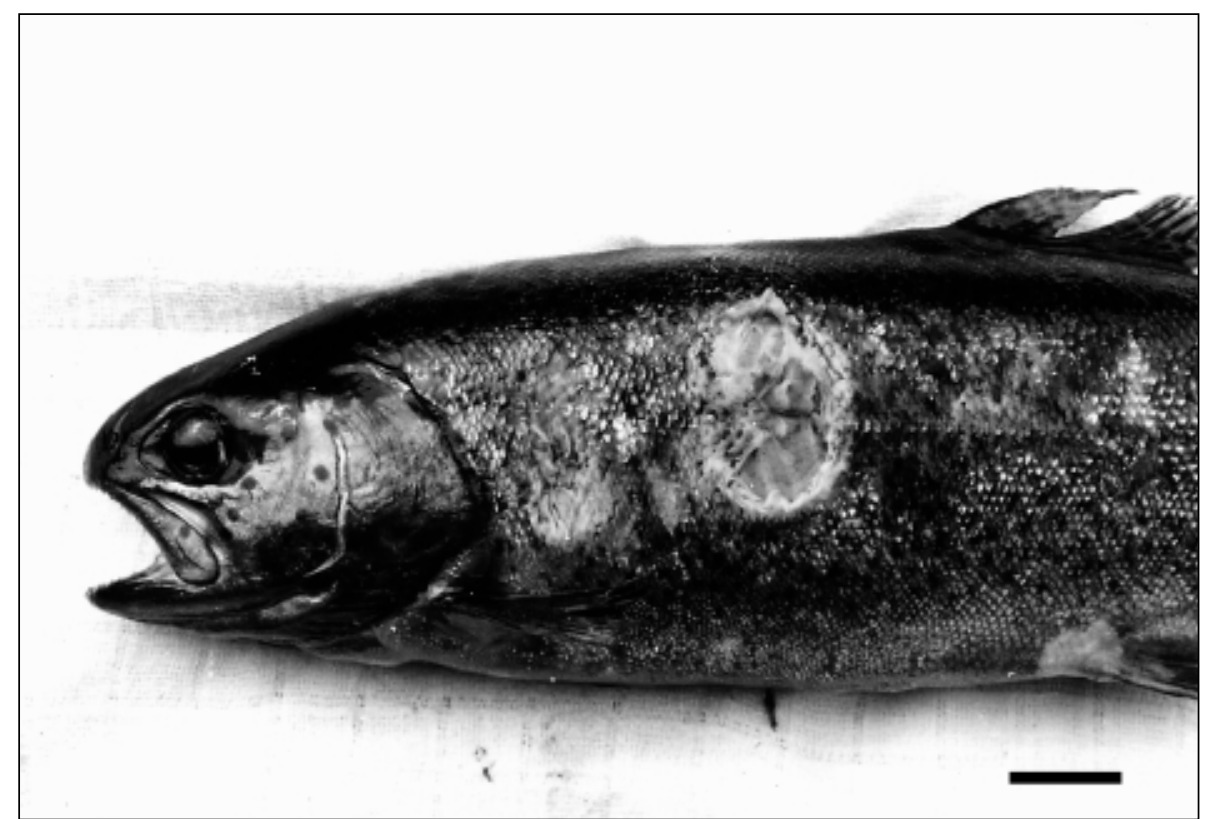

Fig. 2. Erosion results in a necrotic ulcerative lesion. Bar $=20 \mathrm{~mm}$. 


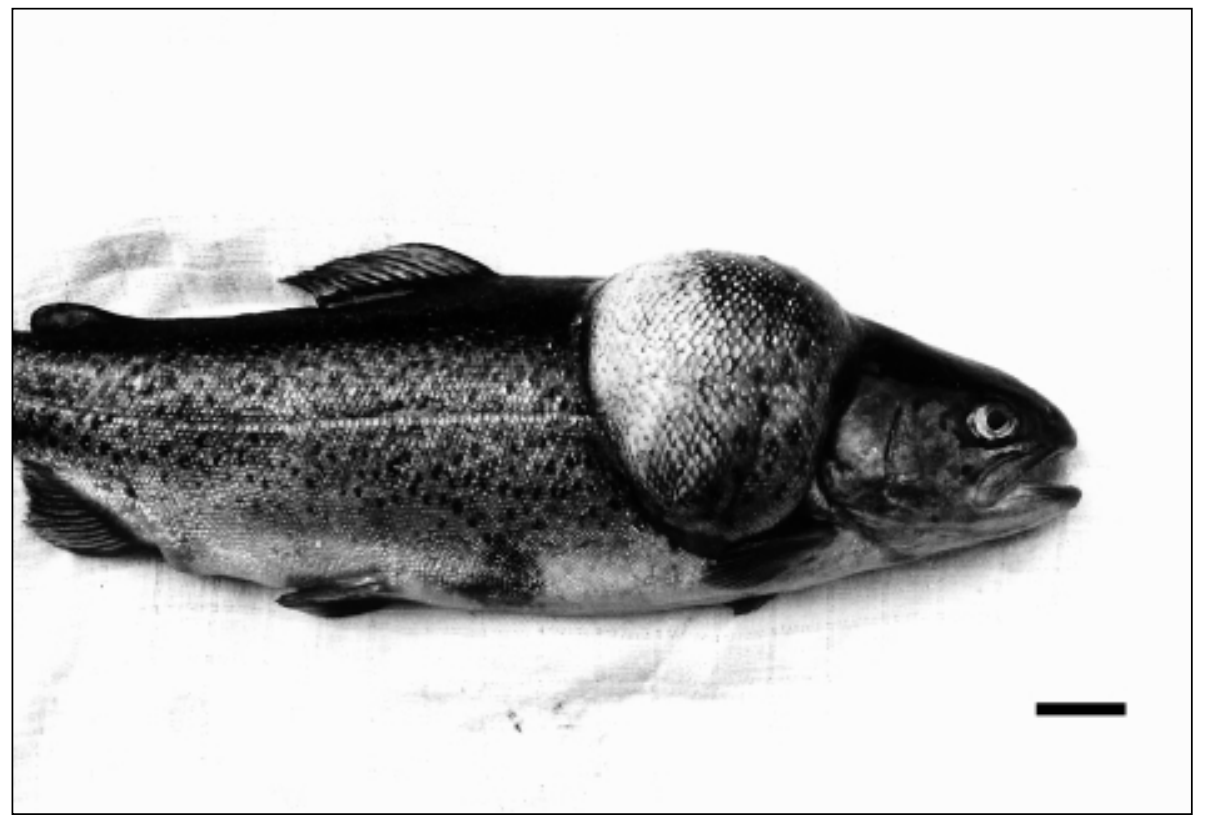

Fig. 3. Enormous subcutaneous bulge filled with a clear to slightly turbid exudate. $B a r=20 \mathrm{~mm}$

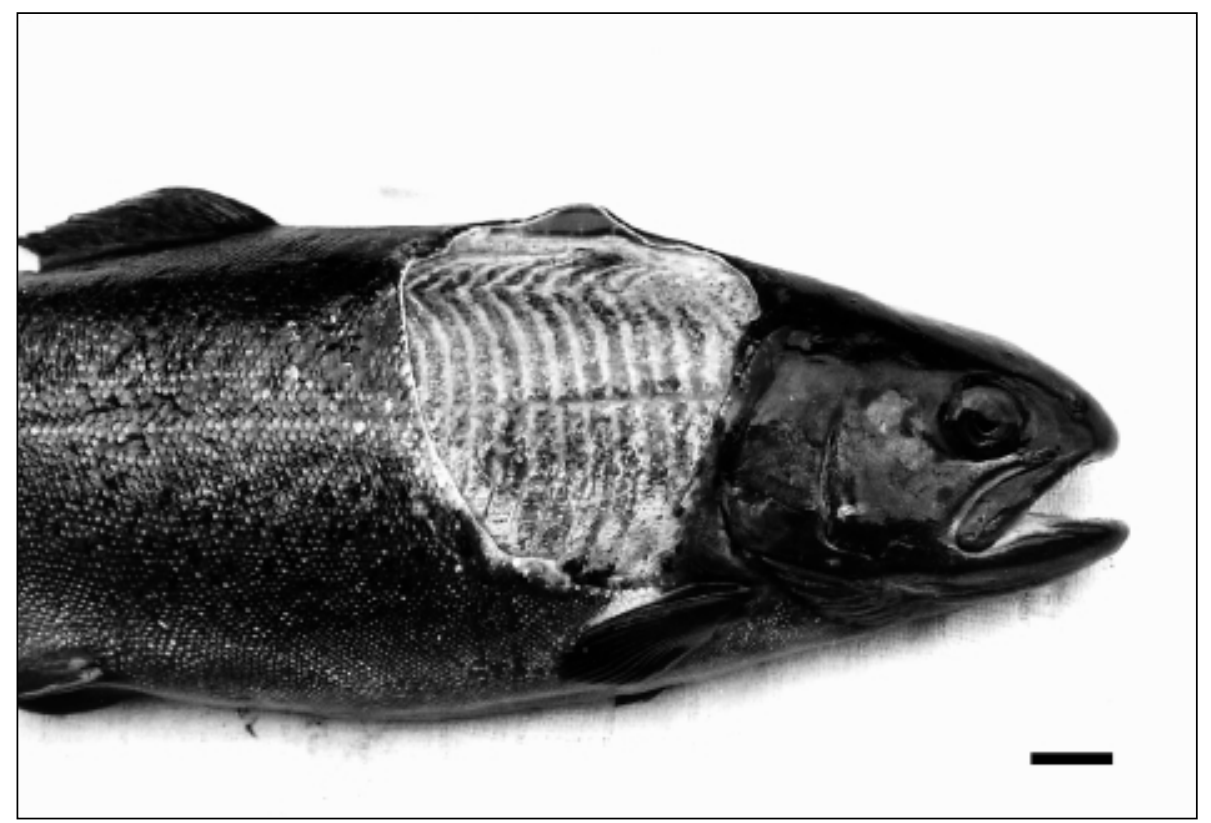

Fig. 4. Haemorrhagically altered muscle after cutting off the skin (this is the fish illustrated in Figure 3). Bar $=10 \mathrm{~mm}$. 
Plate XIV

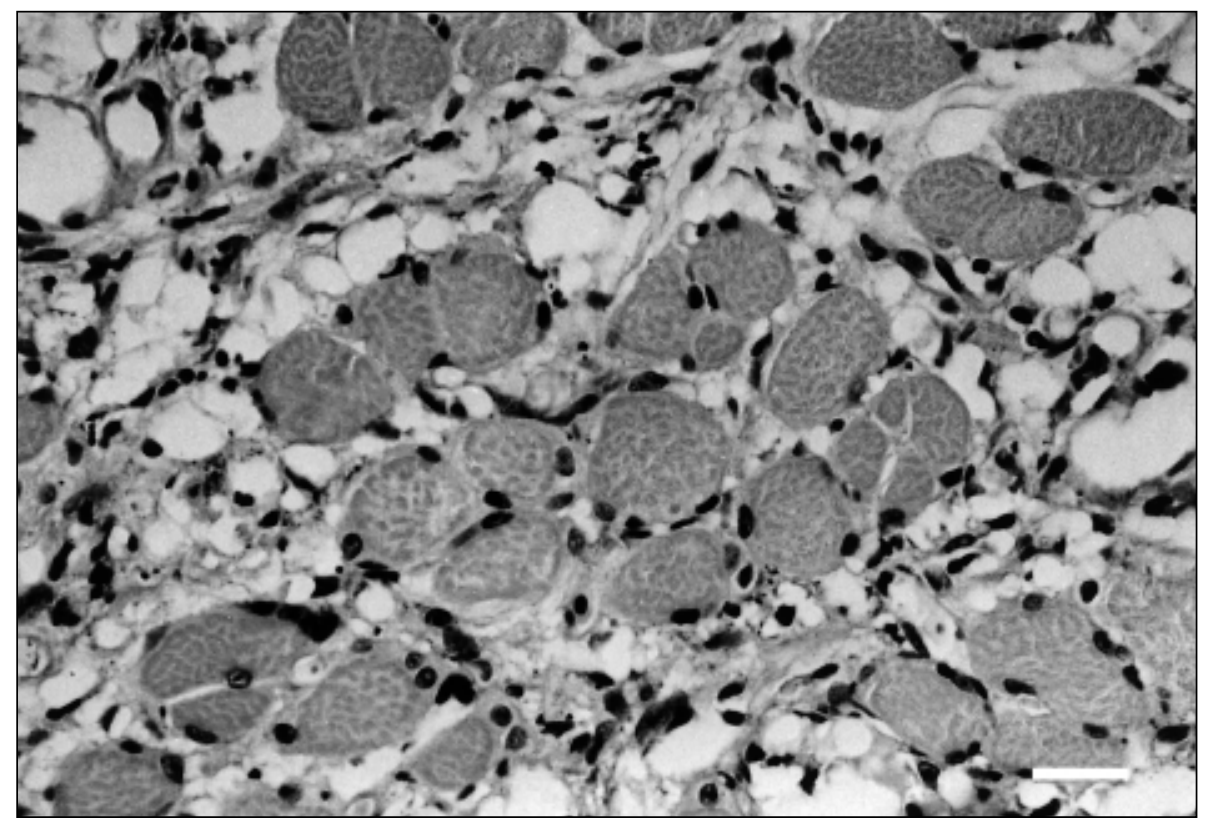

Fig. 5. A more pronounced interstitial inflammation with lipomatous atrophy of the skeletal muscles. Haematoxylin - eosin. Bar $=20 \mu \mathrm{m}$.

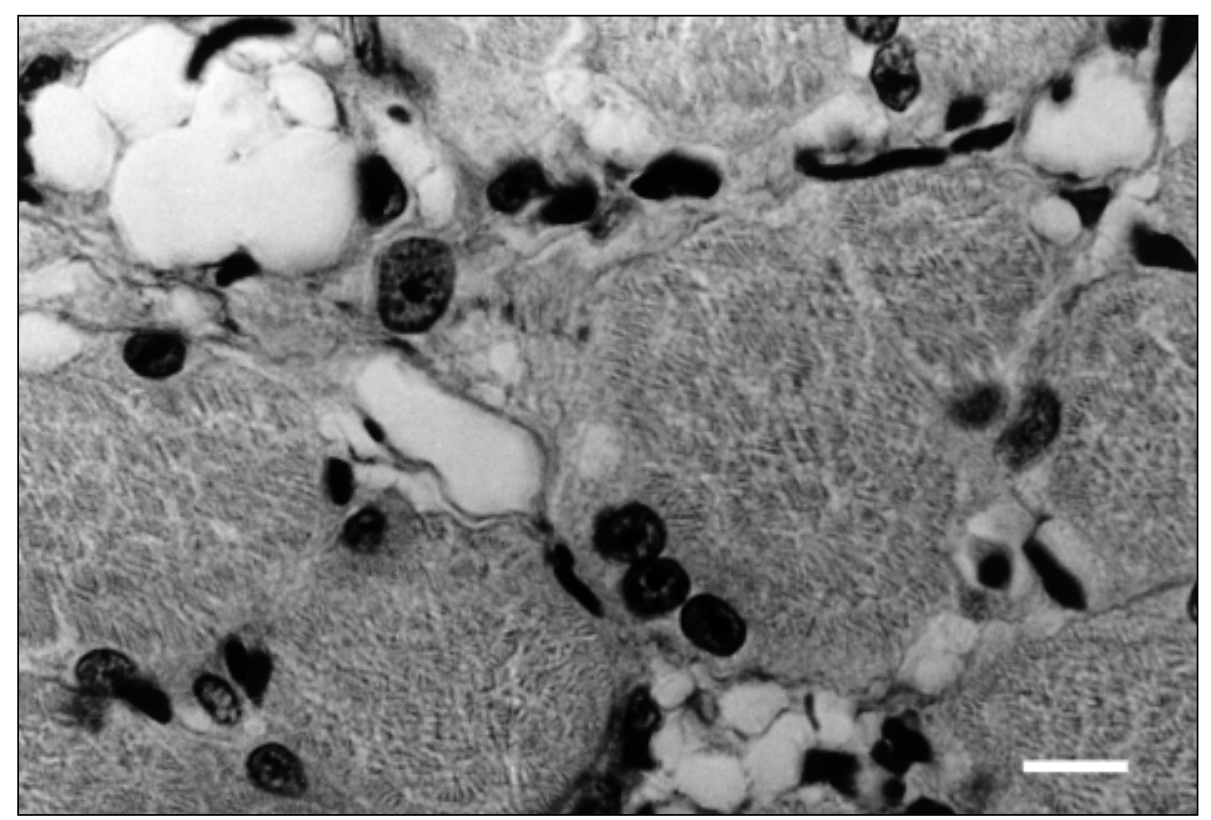

Fig. 6. Detailed view of an atrophy muscle fibers, involving multinuclear muscle fibers. Haematoxylin eosin. $\mathrm{Bar}=10 \mu \mathrm{m}$. 
Plate XV

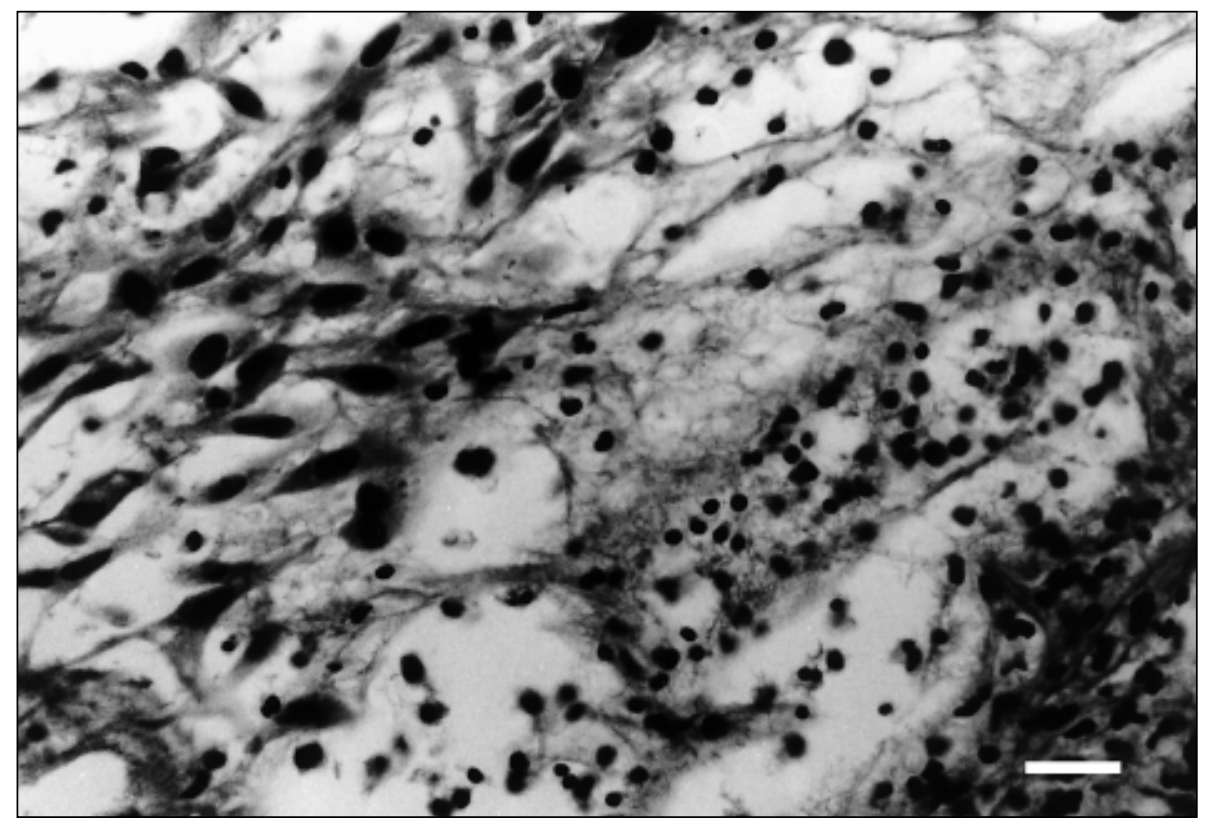

Fig. 7. Subacute inflammatory changes in the pancreas, with the presence of fibroblasts, induced by bacterial agents (experimental infection). Haematoxylin - eosin. Bar $=20 \mu \mathrm{m}$.

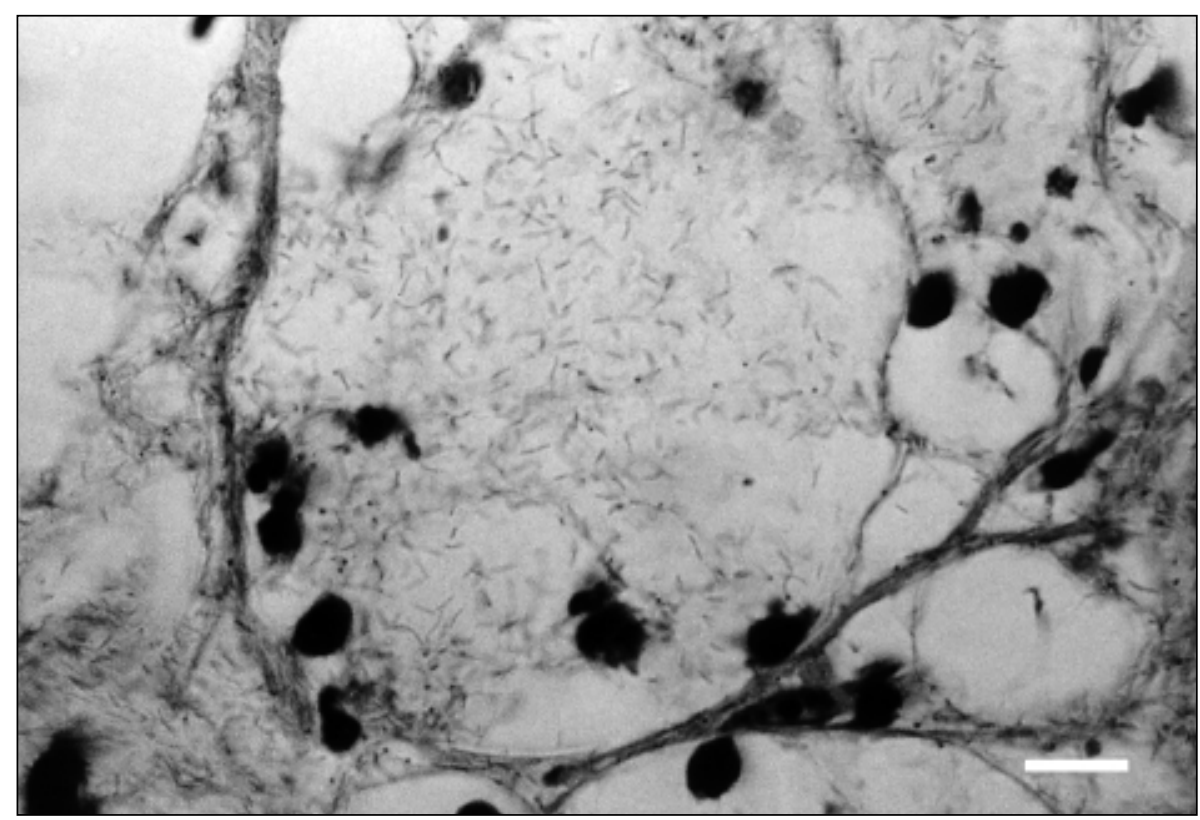

Fig. 8. Detailed view of Fig. 7 with abundant bacteria in the inflammation infiltrate. Gram. Bar $=10 \mu \mathrm{m}$. 
Plate XVI
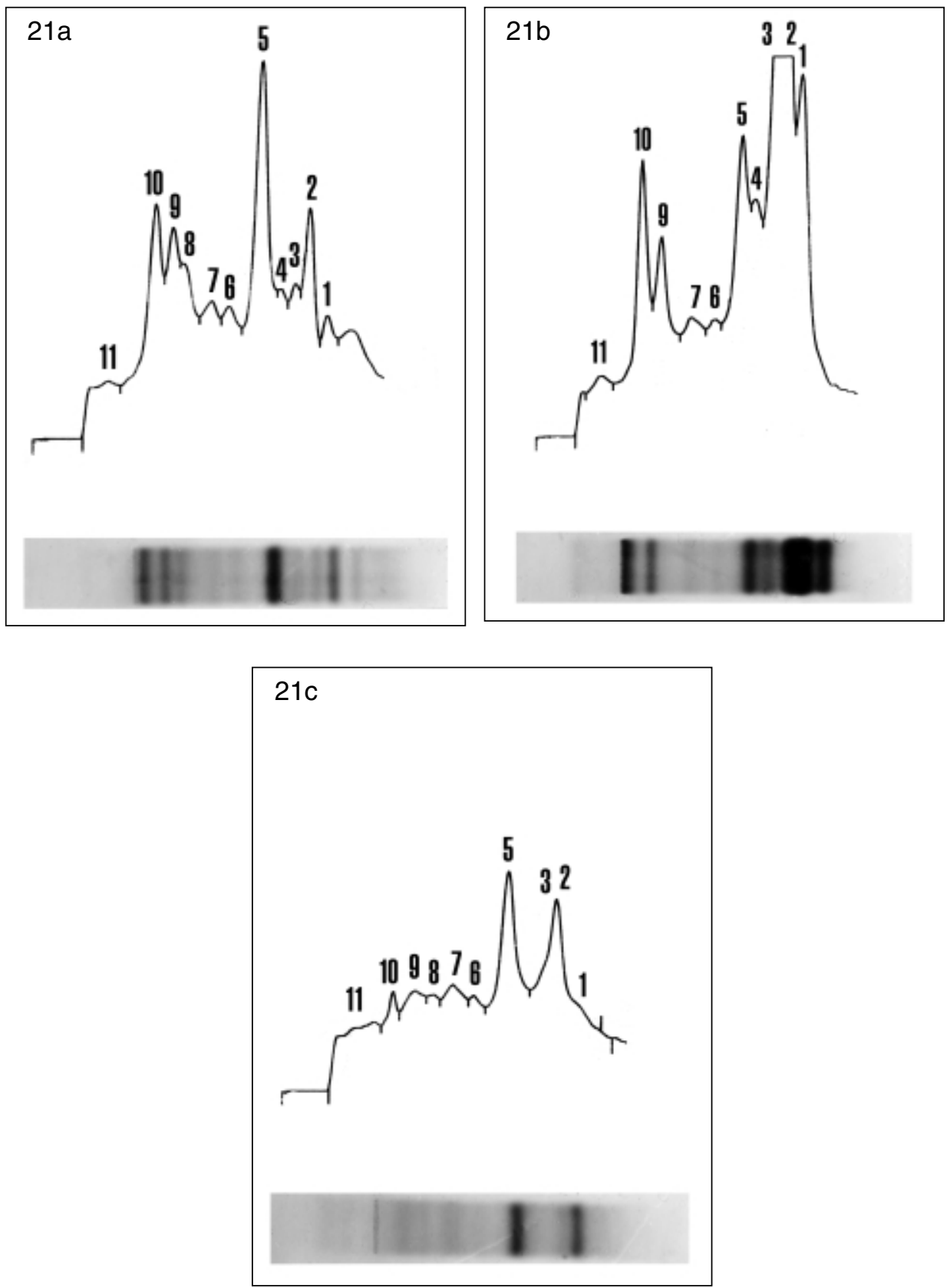

Fig. 21abc. Density distribution of the protein components of the blood plasma of diseased (a) and healthy fish (b) and exudate (c) with electrophoretic record on agarose gel medium 